\title{
Effectiveness of E-learning from Teachers' Perspectives of the Private Universities in Kurdistan Region- Iraq
}

\section{Hero Khwrshid Hassan}

Department of English, College of Education, Bayan University, Erbil, Kurdistan Region, Iraq

hero.kh.h@gmail.com

\section{Awan Kamal Muhammed}

Department of English, College of Languages and Education, Lebanese French University, Erbil, Kurdistan Region, Iraq.

Awan.muhammad@lfu.edu.krd

Awankamal8@gmail.com

\section{ARTICLE INFO}

\section{Article History:}

Received: $4 / 8 / 2021$

Accepted: $13 / 9 / 2021$

Published: Autumn 2021

Keywords: E-learning, technology, barriers, ICT tools.

Doi:

10.25212/Ifu.qzj.6.4.41

\begin{tabular}{l} 
ABSTRACT \\
\hline Technology has a crucial role in different aspects of everyday \\
life, and its importance for education is no different. \\
Technology is swiftly changing the way students learn and \\
teachers teach. There are reasons behind the growth of E- \\
learning industry in higher education, both from the \\
institutions' and students' perspectives. E-learning is an \\
attractive alternative with the limited capacity of existing \\
classrooms at academic institutions and the prohibitive cost \\
of building new facilities. This study examines how effective \\
the e-learning process is through the teachers' perspective at \\
the private universities in Kurdistan. An online survey was \\
utilized to collect data and information, involving 100 \\
participants from the targeted universities. The study \\
hypothesizes that teachers' background has the least impact \\
on the level of the barriers. This study stimulates further \\
obstacles inimplementing the E-learning process in higher \\
education, such as the lack of student's capacity to use ICT \\
tools. In addition to the lack of engagement between the \\
teachers and students during the implementation of E- \\
learning process.
\end{tabular}




\section{QALAAI ZANISTSCIENTIFIC JOURNAL \\ A Scientific Quarterly Refereed Journal Issued by Lebanese French University - Erbil, Kurdistan, Iraq \\ Vol. (6), No (4), Autumn 2021 \\ ISSN 2518-6566 (Online) - ISSN 2518-6558 (Print)}

\section{Introduction}

The World Health Organization (WHO) reported COVID-19, a global emergency on January 30th, 2020 and a worldwide pandemic on March 11th, 2020. As for now, COVID-19 is striking 213 countries and territories (WHO, 2020). Many countries have applied strict health measures such as; social distancing and a curfew policy in response to COVID-19. Certainly, this pandemic has had and still has a significant effect on the education system in general. As of March 12th, 2020, 46 countries in five different continents have declared school closures and 26 of these countries have fully closed schools nationwide (Huang, Liu, Tlili, Yang, \& Wang, 2020). The WHO declared that The first four cases in Kurdistan were confirmed on Sunday, $1^{\text {st }}$ of March 2020 , the cases were from a family returned from Iran. The Data now has been raised to 40,558 cases with a total death of 1,495 cases. In Kurdistan, the Government has implemented mitigating measures in the educational instructions such as schools, colleges, and universities since late February 2020, and restricted community mobilization in an attempt to prevent the spread of the disease and keeps promoting an agenda of work from home, a study from home and worship at home.

According to the World Health Organization (WHO) COVID-19 has been declared a global public health emergency of international concern on 30th January 2020, and as a pandemic on 11th March 2020. COVID-19 is an infectious disease, and a recently found out coronavirus causes it. From the beginning, this disease was known as '2019 novel coronavirus' or '2019 ncov'.

The education process has been stopped since the announcement of CAOVID 19 in Kurdistan and all the educational institutes had been stopped by the authorities. (Kaur, 2020) stated that Coronavirus restricted the experts to re-take into account the former method of face to face learning and they began considering distance teaching as a feasible alternative to fill the classroom void for a period of three to four months, in this way diminishing the danger of spreading the virus among the students before the traditional activities are continued.

To deal with Education process in Kurdistan, teaching and learning have been maintained remotely by applying Information and Communication Technologies (ICT), using different resources and platforms to continually support teachers and 


\section{QALAAI ZANISTSCIENTIFIC JOURNAL \\ A Scientific Quarterly Refereed Journal Issued by Lebanese French University - Erbil, Kurdistan, Iraq \\ Vol. (6), No (4), Autumn 2021 \\ ISSN 2518-6566 (Online) - ISSN 2518-6558 (Print)}

students. Electronic learning (e-learning) has been taken seriously ever since and considered the best possible alternative to continue the teaching and learning process during the pandemic of Coronavirus.

However, the consideration and implementation of e-learning are not always running smoothly and effectively. During the COVID-19 pandemic, schools and universities have quickly approached e-learning. Hence, schools or institutions that have limited or nil experience with e-learning and schools that have not prepared e-learning resources or platforms will face difficulties, especially when teachers are not quite familiar with the process of online applications (Zaharah \& Kirilova, 2020).

\subsection{Purpose of the study:}

The study aims:

1- To know the eligibility of online teaching during the COVID 19 pandemic among the private university facilitators in the ministry of Higher Education in the Kurdistan region.

2- To shed light on the challenges and struggles of online teaching confronted by Higher Education facilitators and possible ways of overcoming them.

\subsection{Method}

The essential aim behind this research is to highlight the overall attitudes of facilitators of the private universities in the Kurdistan region towards the obligatory digital and distance teaching university curriculum in the time of Coronavirus (COVID19). The sample of the study tackles 10 private Universities within the region: (100) the teachers; (49) female and (51) male participants. The participants included PhD holder ( $N=26 \%$ ) as well as M.A. holders ( $N=74, \%$ ) facilitators. All the participants in the survey were currently applied E-teaching with the usage of different digital tools recommended by the administration of their universities.

\section{Data collection and Data resources}

An online google form questionnaire was used to collect data. The first reason for using an online questionnaire was the suitability of the teachers' timeline work during the pandemic. Furthermore, the data in the online questionnaire were easy to be 


\section{QALAAI ZANISTSCIENTIFIC JOURNAL}

A Scientific Quarterly Refereed Journal Issued by Lebanese French University - Erbil, Kurdistan, Iraq

Vol. (6), No (4), Autumn 2021

ISSN 2518-6566 (Online) - ISSN 2518-6558 (Print)

registered and collected and at the same time to be accessed through different

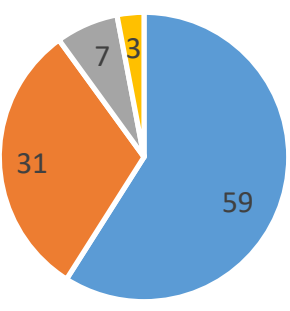

$=25-35=36-45=46-55=56-a b o v e$

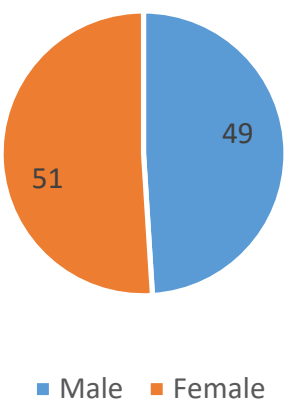

Figure 2: Gender

devices, including smartphones (Fraenkel et al., 2011). The questionnaires were distributed and sent to the lecturers after universities had been closed and they had been instructed to use online learning. The questionnaires were approached through Viber groups, Edmodo, the official Facebook group for Kurdistan University lecturers, and also official emails of the universities. Proper revisions and adjustments were made dependent on their remarks and suggestions. 


\section{QALAAI ZANISTSCIENTIFIC JOURNAL}

A Scientific Quarterly Refereed Journal Issued by Lebanese French University - Erbil, Kurdistan, Iraq

Vol. (6), No (4), Autumn 2021

ISSN 2518-6566 (Online) - ISSN 2518-6558 (Print)

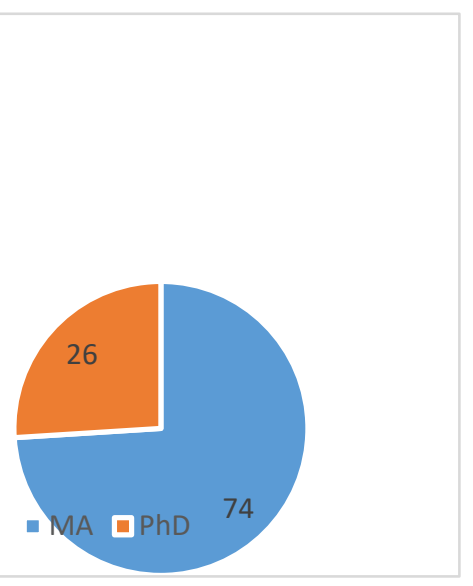

Figure 3: Certificate

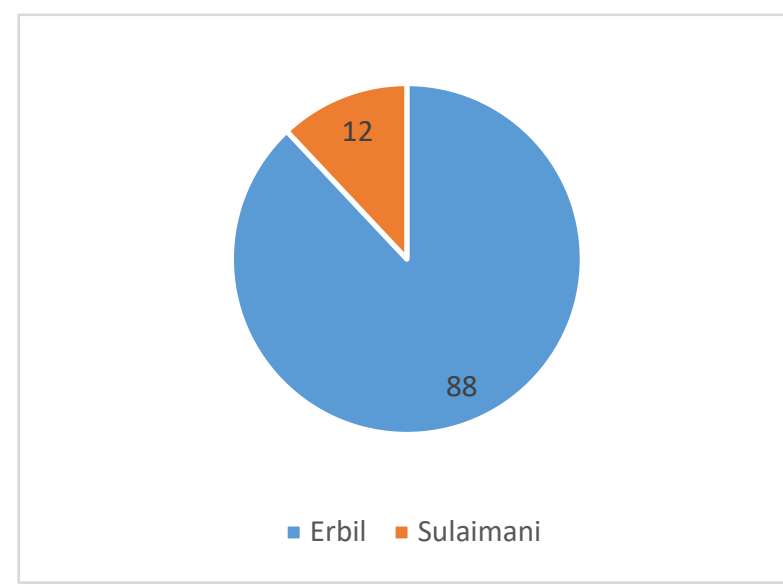

Figure 4: Governorate

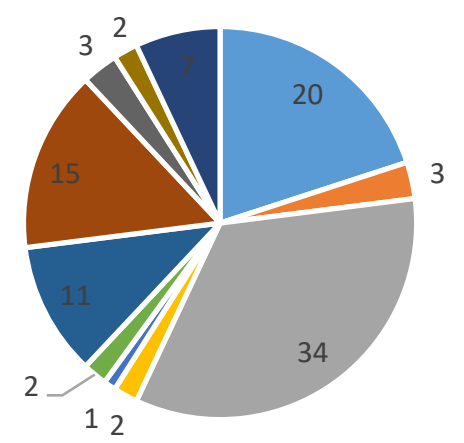
- Lebanese French University
- Cihan University-Suli
- Bayan University
- Catholic University
- Komar University of Science and Technology = Tishk International University-Suli
- Knowledge University
- Cihan University-Erbil
- University of Human Development
- AUIS
- Tishk International University Erbil

Figure 5: List of the targeted Universities 


\section{QALAAI ZANISTSCIENTIFIC JOURNAL}

A Scientific Quarterly Refereed Journal Issued by Lebanese French University - Erbil, Kurdistan, Iraq

Vol. (6), No (4), Autumn 2021

ISSN 2518-6566 (Online) - ISSN 2518-6558 (Print)

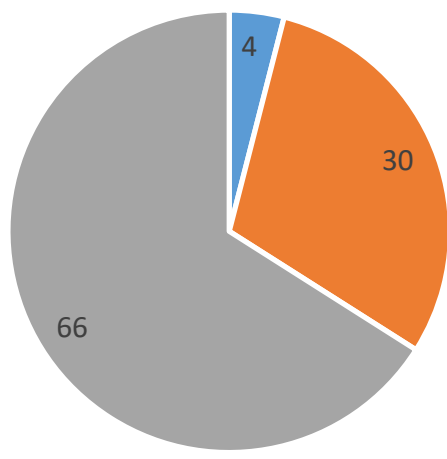

- I am not prepared - I am partially prepared

- I am well prepared

Figure 6: As a teacher, are you well prepared to conduct online lectures?

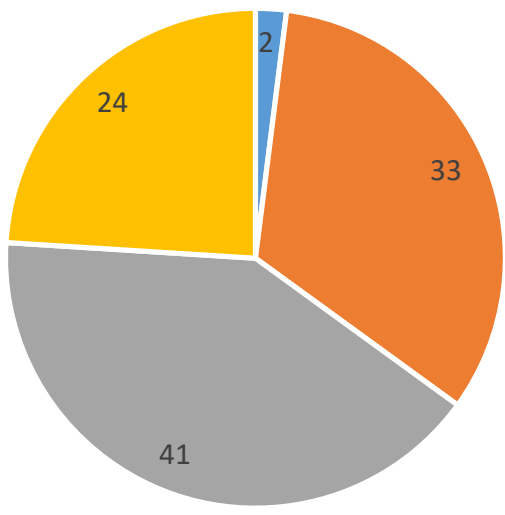

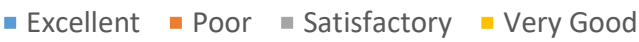

Figure 7: How do you rate the effectiveness of the E-learning process in general?

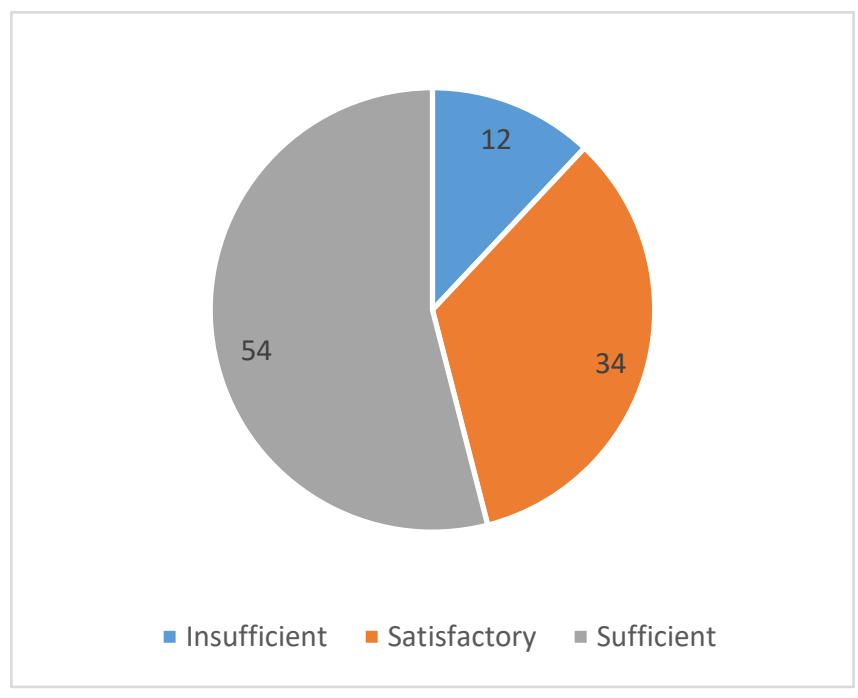

Figure 8: As a teacher, how would you rate your capacity to manage E-learning process in terms of your software skills? 


\section{QALAAI ZANISTSCIENTIFIC JOURNAL}

A Scientific Quarterly Refereed Journal Issued by Lebanese French University - Erbil, Kurdistan, Iraq

Vol. (6), No (4), Autumn 2021

ISSN 2518-6566 (Online) - ISSN 2518-6558 (Print)

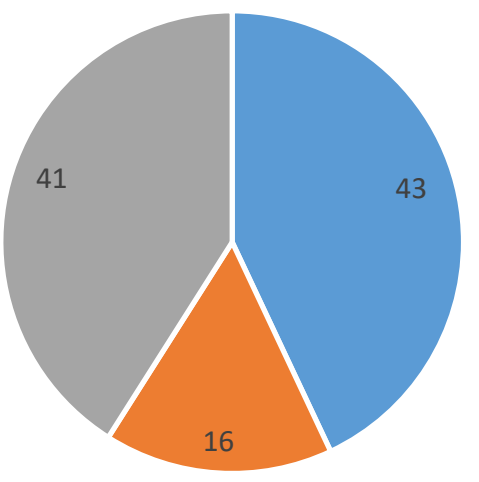

- Half of the students meet the requirements

- Majority of the students meet the requirements

- Minority of the students meet the requirements

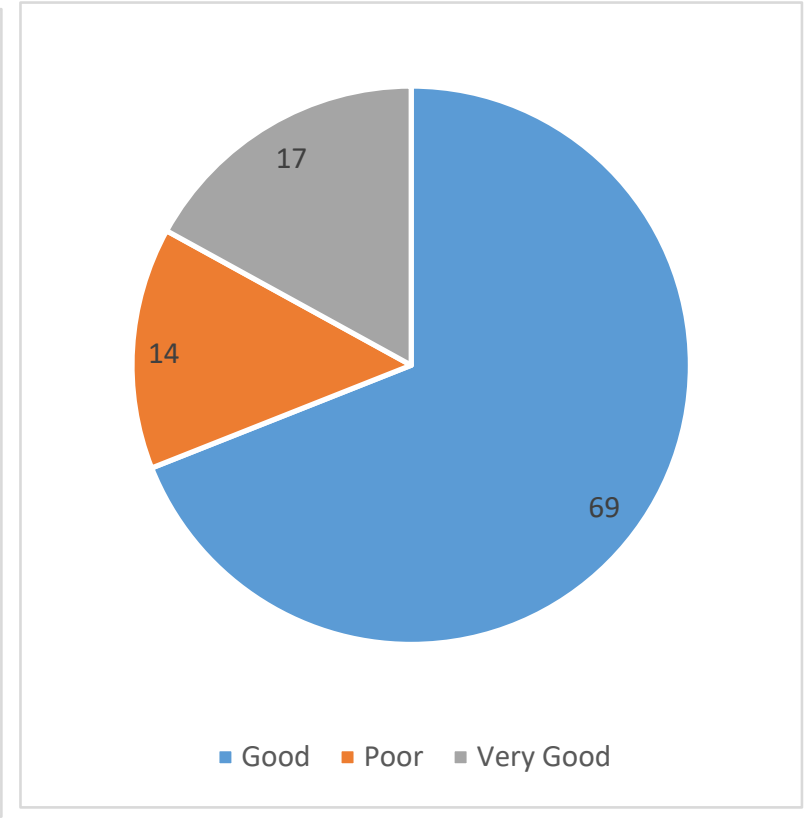

Figure 9: To your knowledge, do your students meet all the requirements to participate actively in the E-learning process?

Figure 10: How would you rate/assess the general capacity of your university for the E-leaning process?

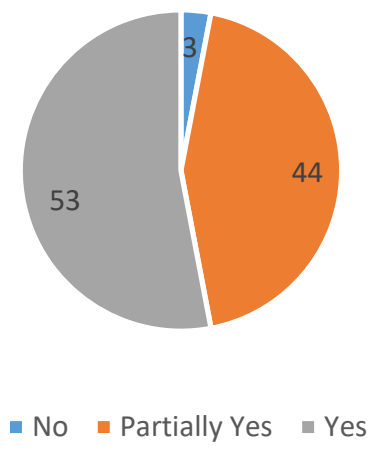

Figure 11- Has your university provided you with the required guidance and training for the E-learning process? 


\section{QALAAI ZANISTSCIENTIFIC JOURNAL}

A Scientific Quarterly Refereed Journal Issued by Lebanese French University - Erbil, Kurdistan, Iraq

Vol. (6), No (4), Autumn 2021

ISSN 2518-6566 (Online) - ISSN 2518-6558 (Print)

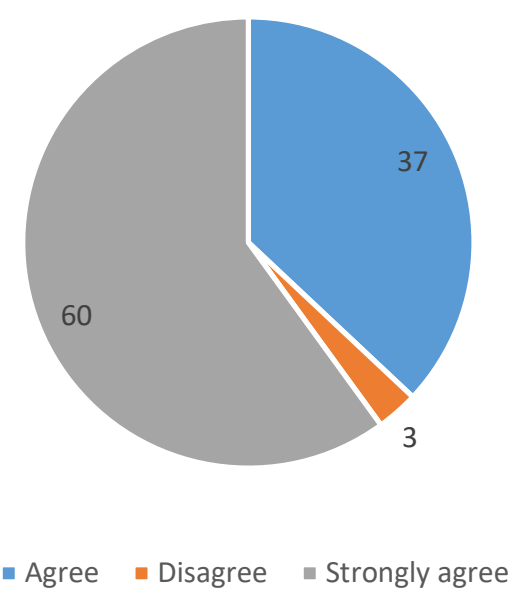

Figure 12- Teaching on campus is much more effective and productive than E-learning?

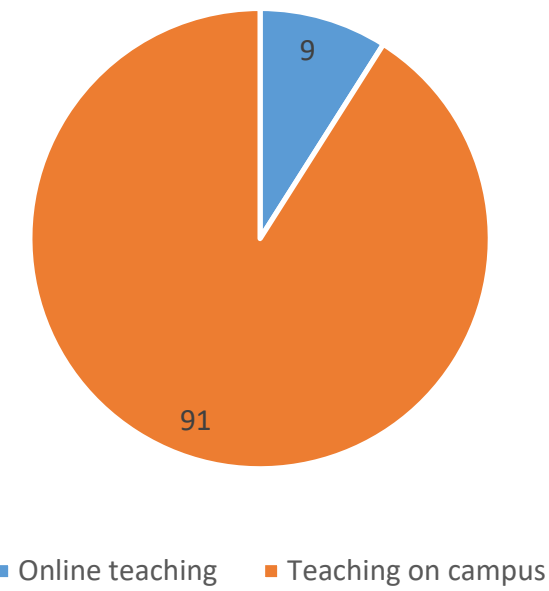

Figure 13- If you are given the choice of teaching on campus or teaching online, which one you will choose? 


\section{QALAAI ZANISTSCIENTIFIC JOURNAL}

A Scientific Quarterly Refereed Journal Issued by Lebanese French University - Erbil, Kurdistan, Iraq

Vol. (6), No (4), Autumn 2021

ISSN 2518-6566 (Online) - ISSN 2518-6558 (Print)

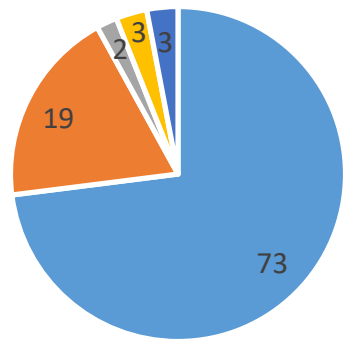

- Better training for teachers, Enhancing student's technical capacity, Enriching the available resources

- Enhancing student's technical capacity, Enriching the available resources, Raising awareness of the students about the importance of E-learning

- Enriching the available resources, Raising awareness of the students about the importance of Elearning

- Motivating the teachers

- Raising awareness of the students about the importance of E-learning

Figure 14- In your opinion, how can we improve e-learning process and make it more effective? Mention at least three ways

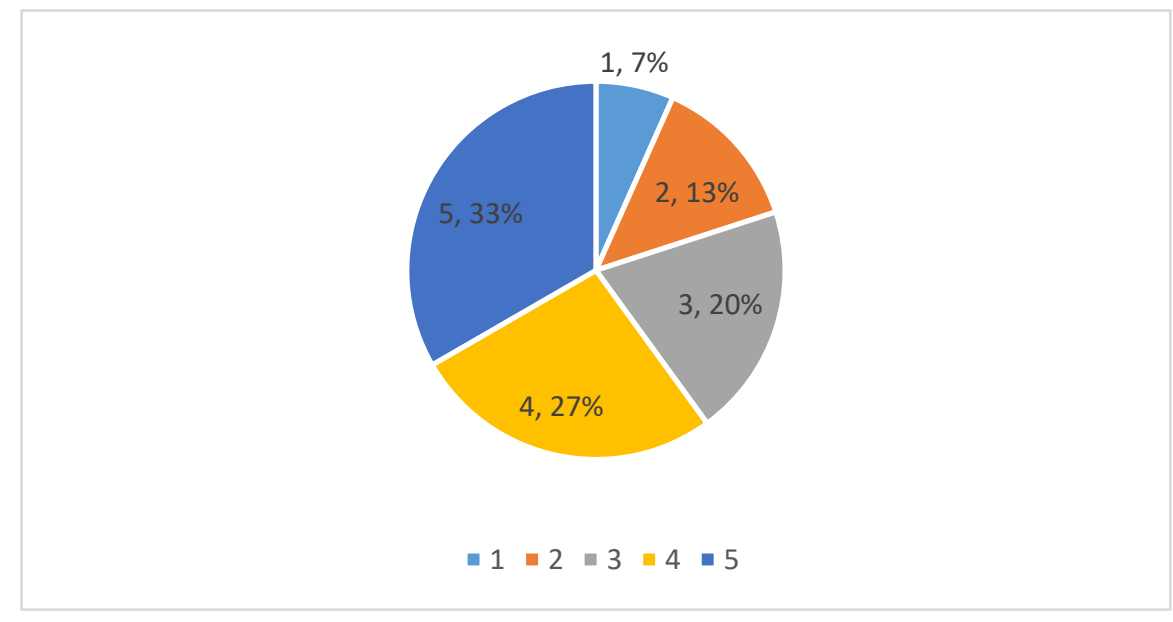

Figure 15- How would you rate the accountability level of the university towards Elearning process? 1 for worst and 5 for best 


\section{QALAAI ZANISTSCIENTIFIC JOURNAL}

A Scientific Quarterly Refereed Journal Issued by Lebanese French University - Erbil, Kurdistan, Iraq

Vol. (6), No (4), Autumn 2021

ISSN 2518-6566 (Online) - ISSN 2518-6558 (Print)

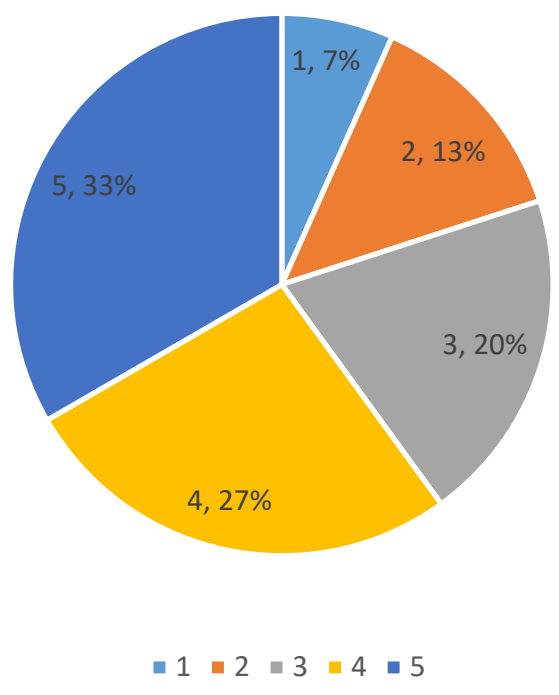

Figure 16- How would you rate the level accountability of yourself as a teacher towards E-learning process? 1 for worst and 5 for best

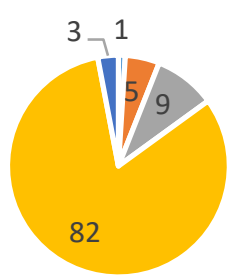

- Financial issues which might demotivate the teachers

- Inequality of the distributed tasks among the teachers (some teachers have more responsibilities)

- Insufficient technical skills of the teachers to perform E-teaching

- Poor participation by the students

- University doesn't offer the required resources in terms of software system and training opportunities

Figure 17- What might be some of the challenges faced by the teachers in the Elearning process? 


\section{QALAAI ZANISTSCIENTIFIC JOURNAL \\ A Scientific Quarterly Refereed Journal Issued by Lebanese French University - Erbil, Kurdistan, Iraq \\ Vol. (6), No (4), Autumn 2021 \\ ISSN 2518-6566 (Online) - ISSN 2518-6558 (Print)}

\subsection{Discussion and result:}

The participants were asked to identify at least the top three advantages of the elearning process. To them, the top advantages include safety education during the COVID period because people can keep social distance and even get education remotely. Also, students can have access to education anywhere and get information from different sources/countries. In addition to these, e-learning can be costeffective and time-saving as well as enhance teachers' and students' ICT skills due to the continuous practice of the electronic education process.

Furthermore, Teachers were requested to mention top disadvantages of the ELearning process. Their responses included concerns such as lack of students' participation, facing technical problems by both teachers and students, and poor internet connection in the country, which has a negative impact process. Other disadvantages include lack of controlling the classroom by the teachers, lack of engagement and interaction between the teacher and the students. In addition to the fact that the e-learning process is a more theoretical method rather than practical.

Finally, participants were asked to suggest possible ways for making the e-learning process more effective. They shared different recommendations such as raising students' awareness through training courses about the importance of the E-leaning, providing technical support for students and making the E-Learning process compulsory. Moreover, they suggested creating a strong connection and using suitable online applications, training the teachers and the students in addition to the use of a unified system to monitor the process

\section{Conclusion:}

Overall, this research concludes that the university lecturers at the private universities in KRG face problems with the implementation of E-learning as a tool of instruction in higher education. Their most significant challenges at the student level are students' engagement in the process and their lack of knowledge and awareness. It also sheds light on the correlation between the teachers and the students regarding the technical level of the e-learning platforms and the interaction between the two parties. These reasons and aforementioned points all make barriers and difficulties 


\section{QALAAI ZANISTSCIENTIFIC JOURNAL}

A Scientific Quarterly Refereed Journal Issued by Lebanese French University - Erbil, Kurdistan, Iraq

Vol. (6), No (4), Autumn 2021

ISSN 2518-6566 (Online) - ISSN 2518-6558 (Print)

for the teachers and the students to maintain a healthy and academic electronic study environment.

\section{References:}

Fraenkel, J. R., Wallen, N. E., \& Hyun, H. H. (2011). How to design and evaluate research in education: New York: McGraw-Hill Humanities/Social Sciences/Languages.

Huang, R., Liu, D., Tlili, A., Yang, J., \& Wang, H. (2020). Handbook on Facilitating Flexible Learning During Educational Disruption: The Chinese Experience in Maintaining Undisrupted Learning in COVID-19 Outbreak. Beijing: Smart Learning Institute of Beijing Normal University.

WHO. (2020). Coronavirus disease (COVID-19) pandemic. 2020, from https://www.who.int/

K. Werback, "Clicks and mortar meets cap and gown: Higher Education goes online" Release 1.0, 2000, 18 (8), 1-22.

Kaur, G. (2020). Digital Life: Boon or bane in teaching sector on COVID-19. CLIO an Annual Interdisciplinary Journal of History, 6(6), 416-427.

Zaharah, Z., \& Kirilova, G. I. (2020). Impact of Corona Virus Outbreak Towards Teaching and Learning Activities in Indonesia. SALAM: Jurnal Sosial dan Budaya Syari, 7(3). https://doi.org/10.15408/ sjsbs.v7i3.15104 


\section{QALAAI ZANISTSCIENTIFIC JOURNAL}

A Scientific Quarterly Refereed Journal Issued by Lebanese French University - Erbil, Kurdistan, Iraq

Vol. (6), No (4), Autumn 2021

ISSN 2518-6566 (Online) - ISSN 2518-6558 (Print)

كارايى فيّربوونى ئهليكتروّنى له تيّروانينى ماموّستايانى زانكوّ تايبهتهكانى ههريّمى كوردستانى عِيرِاق.

يـوختـه:

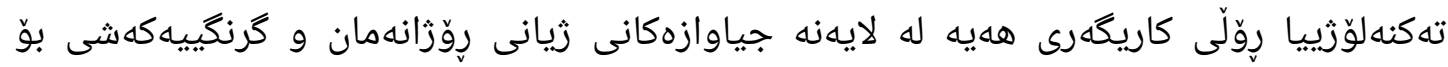

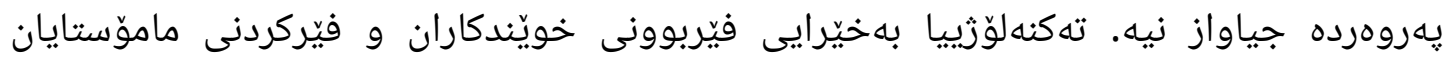

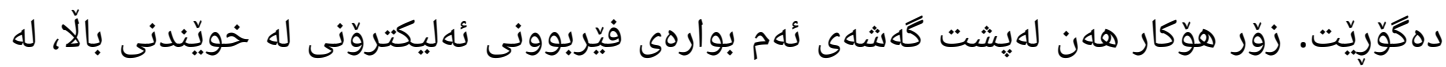

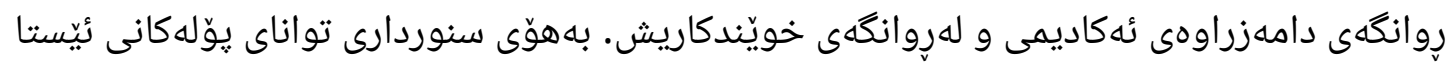

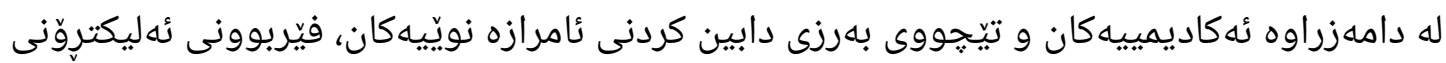

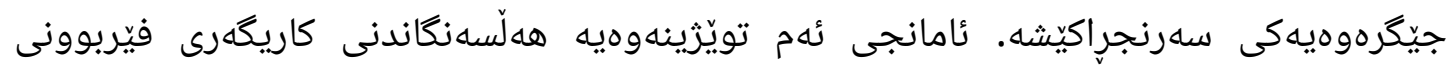

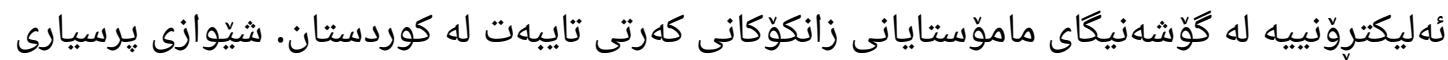

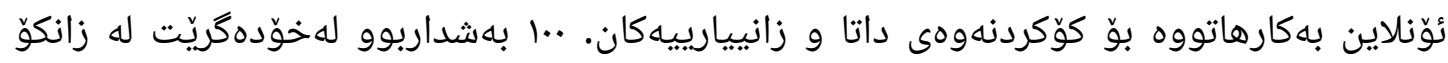

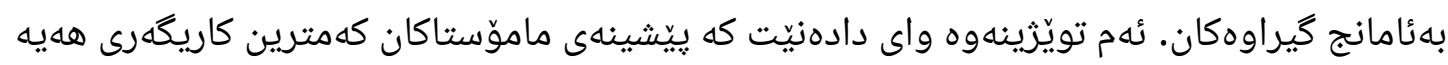

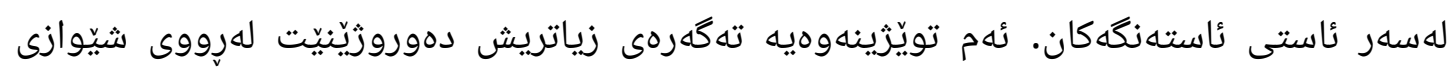

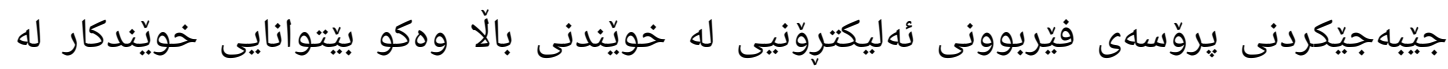

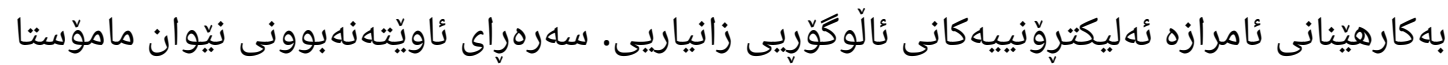

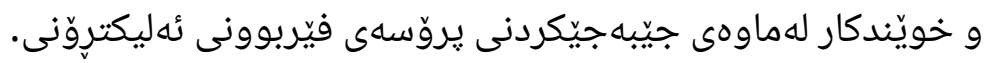
كليله وشه:

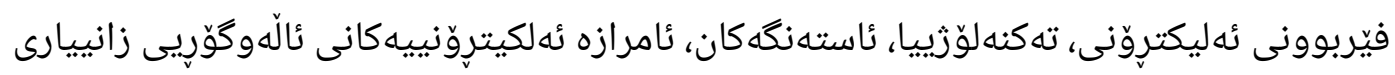




\section{QALAAI ZANISTSCIENTIFIC JOURNAL}

A Scientific Quarterly Refereed Journal Issued by Lebanese French University - Erbil, Kurdistan, Iraq

Vol. (6), No (4), Autumn 2021

ISSN 2518-6566 (Online) - ISSN 2518-6558 (Print)

فاعلية التعلم الإكتروني من وجهة نظر الأساتيذ في الجامعات الخاصة في إقليم كوردستان العراق

الملخص:

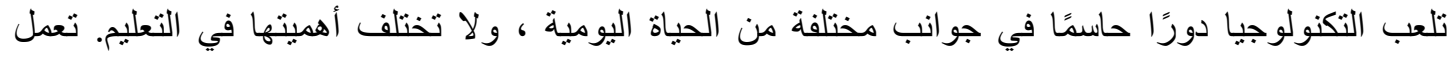

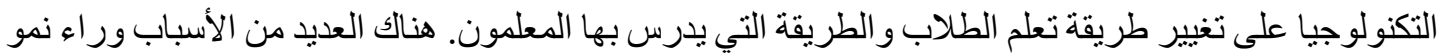

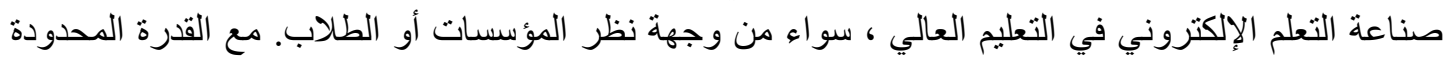

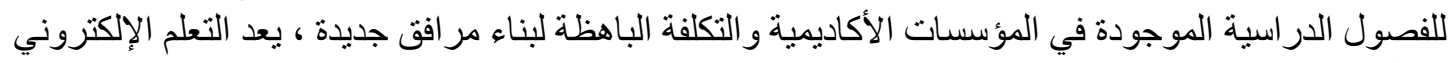

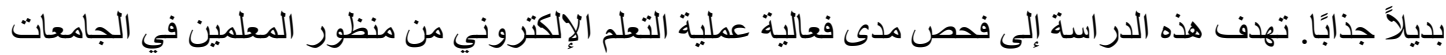

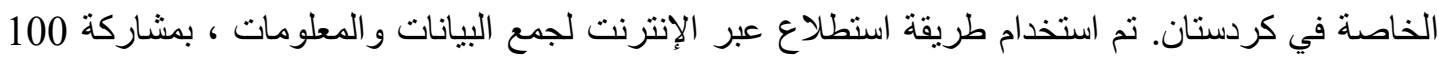

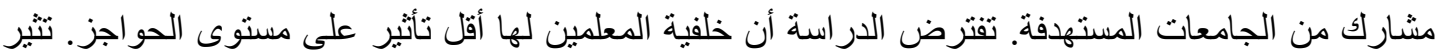

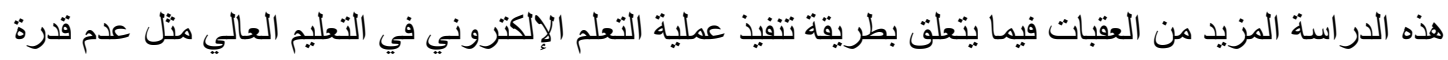

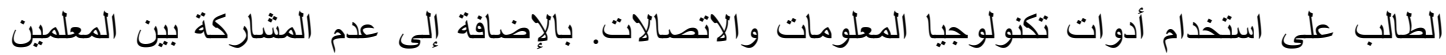
والطلاب أثناء تنفيذ عملية التعلم الإلكتروني.

الكلمات المفتاحية: لتعلم الإلكتروني ، التكنولوجيا ، الحواجز ، أدوات تكنولوجيا المعلومات والاتصالات. 